\title{
Erratum: Novel Immune Check-Point Regulators in Tolerance Maintenance
}

\section{Frontiers Production Office* \\ Frontiers Production Office, Frontiers, Switzerland}

Keywords: B7, butyrophilin, immune tolerance

\section{A Erratum on:}

OPEN ACCESS

Approved by:

Immunology Editorial Office,

Frontiers, Switzerland

${ }^{*}$ Correspondence: Frontiers Production Office production.office@frontiersin.org

Specialty section: This article was submitted to Immunological Tolerance, a section of the journal Frontiers in Immunology

Received: 25 January 2016 Accepted: 25 January 2016 Published: 08 February 2016

Citation: Frontiers Production Office (2016) Erratum: Novel Immune Check-Point Regulators in Tolerance Maintenance. Front. Immunol. 7:38. doi: 10.3389/fimmu.2016.00038

\section{Novel Immune Check-Point Regulators in Tolerance Maintenance \\ by Guo Y and Wang AY. Front Immunol (2015) 6:421. doi: 10.3389/fimmu.2015.00421}

\section{Reason for Erratum:}

Due to an error, a citation of Pawar et al. (1), referenced in the last paragraph of section B7-H4, was missing from the Reference List. The full reference should be:

Pawar RD, Goilav B, Xia Y, Herlitz L, Doerner J, Chalmers S, et al. B7x/B7-H4 modulates the adaptive immune response and ameliorates renal injury in antibody-mediated nephritis. Clin Exp Immunol (2015) 179:329-43. doi: 10.1111/cei.12452

The publisher apologizes for this mistake.

This error does not change the scientific conclusions of the article in any way.

\section{REFERENCE}

1. Pawar RD, Goilav B, Xia Y, Herlitz L, Doerner J, Chalmers S, et al. B7x/B7-H4 modulates the adaptive immune response and ameliorates renal injury in antibody-mediated nephritis. Clin Exp Immunol (2015) 179:329-43. doi:10.1111/cei.12452

Conflict of Interest Statement: The authors declare that the research was conducted in the absence of any commercial or financial relationships that could be construed as a potential conflict of interest.

Copyright (c) 2016 Frontiers Production Office. This is an open-access article distributed under the terms of the Creative Commons Attribution License (CC BY). The use, distribution or reproduction in other forums is permitted, provided the original author(s) or licensor are credited and that the original publication in this journal is cited, in accordance with accepted academic practice. No use, distribution or reproduction is permitted which does not comply with these terms. 